\title{
The quality of sour cherry fruits (Prunus cerasus L.), treated with chitosan solution before storage
}

\author{
Olena VASYLYSHYNA ${ }^{1}$
}

Received June 08, 2018; accepted November 14, 2018.

Delo je prispelo 08. junija 2018, sprejeto 14. novembra 2018.

\begin{abstract}
The article shows the results of the research into marketability evaluation of sour cherry (Prunus cerasus L.) fruits, treated with chitosan solution. To achieve this goal, fruits were treated with $0.5 \%$ or $1 \%$ chitosan solution, and stored at $5{ }^{\circ} \mathrm{C}$ for 21 days. To assess the shelf life of fruit, physical and chemical parameters were determined: mass loss, reduction of sugar, titrated acidity and ascorbic acid content. Treatment with chitosan solution significantly reduced the mass loss, content of sugar, acids, ascorbic acid and respiration rate. The treatment with chitosan solution extended the shelf life and improved the quality of sour cherry fruit. After 21-day storage of sour cherries, mass loss was $4.6 \%$ with the product output accounting for $85.5 \%$. The obtained results are approved by physiological and chemical changes in the fruits during storage: respiration rate of fruits decreases, loss of sugar does not exceed $6.7 \%$, acids $-33 \%$ and ascorbic acid $-18 \%$. It has been found that post-harvest treatment with $1 \%$ chitosan solution has a positive influence on commercial quality of sour cherry fruits.
\end{abstract}

Key words: sour cherry fruit; storage; mass loss; commercial quality; chitosan
IZVLEČEK

\section{KAKOVOST PLODOV VIŠNJE (Prunus cerasus L.), TRETIRANIH Z RAZTOPINO HITOZANA PRED SHRANJEVANJEM}

Prispevek obravnava tržno ovrednotenje plodov višnje (Prunus cerasus L.) tretiranih z raztopino hitozana. Plodovi so bili tretirani z $0,5 \%$ in $1 \%$ raztopino hitozana in shranjeni pri $5{ }^{\circ} \mathrm{C}$ za 21 dni. Za ovrednotenje poličnega trajanja plodov so bili izmerjeni naslednji fizikalni in kemični parametri: izguba mase, zmanjšanje vsebnosti sladkorjev in askorbinske kisline ter zmanjšanje titracijske kislosti. Obdelava $\mathrm{z}$ raztopino hitozana je značilno zmanjšala izgubo mase, vsebnost sladkorjev, celokupnih kislin, askorbinske kisline in velikost dihanja. Obdelava s hitozanom je podaljšala polično trajanje višenj in izboljšala njihovo kakovost. Po 21-dneh shrambe se je masa višenj zmanjšala za $4,6 \%$, celoten pridelek pa na $85,5 \%$. To so potrdile naslednje fiziološke in kemične spremembe $\mathrm{v}$ plodovih med shranjevanjem: upad dihanja plodov, izguba sladkorjev, ki ni presegla $6,7 \%$, vsebnost kislin se je zmanjšala za $33 \%$ in askorbinske kisline za $18 \%$. Ugotovljeno je bilo, da je imela obdelava plodov višenj z $1 \%$ raztopino hitozana po obiranju pozitivni vpliv na njihovo tržno kakovost.

Ključne besede: plodovi višenj; shranjevanje; izguba mase; tržna kakovost; hitozan

\section{INTRODUCTION}

Sour cherry (Prunus cerasus L.) is one of the most appreciated fruit by consumers due to its excellent quality. Sour cherry fruits are the source of acids, vitamins and anthocyanins (Chernozubenko, 1993). However, they have a limited shelf life, which is only 15 days. To prolong the shelf life, pre- and postharvest treatment with substances of antimicrobial action, Aloe vera (L.) Burm.f. cover, or 1-methylcyclopropene (1MCP) are used (Paronian et al., 2003; Yen et al., 2008; Ahmed et al., 2009). However, the use of these substances is not fully studied and 1-MCP is expensive to use. Therefore, chitosan is more widely applied for post-harvest treatment of fruit before storage, including sweet cherry, strawberries, grapes (Romanazzi, 2010).

Chitosan as polysaccharide is a biopolymer and is used in agriculture, biotechnology, food industry, due to its biocompatibility and bioactivity (Wu et al., 2005). In 2001 chitosan was included in the list of secure compounds and foodstuffs in the USA. This natural polymer is derived from chitin by deacetylation and can form a film on treated surfaces, slowing down respiration rate, reducing mass loss, improving quality and prolonging shelf life (Romanazzi et al., 2003;

1 Uman National University of Horticulture, Institutska 1, Uman city, 20305, Ukraine; e-mail: elenamila@i.ua 
Romanazzi, 2010; Romanazzi et al., 2013; Romanazzi et al., 2015). Moreover, chitosan films have selective penetrability to carbon dioxide and oxygen, antibacterial and fungitoxic properties.

Besides other, acting as protective barriers, these films can be used as carriers of bioactive compounds with antioxidant or antibacterial properties (Genskowsky et al., 2015). Therefore, it is used for pre-harvest treatment of grapes, strawberries, cherries and others (El Ghaouth et al., 1991; Romanazzi et al., 2006; Romanazzi et al., 2007; Hernandez-Munoz, 2008; Romanazzi, 2010). According to the literature (El Ghaouth et al., 1991), $1 \%$ and $1.5 \%$ chitosan coatings are used for treatment of strawberries, while storing them at a temperature $4{ }^{\circ} \mathrm{C}$. After 29 days its commercial quality is reduced to
19-22\% compared to $33 \%$ in untreated fruits. In addition, respiration rate of treated fruits is also lower.

Chitosan combined with ethanol or warm water or calcium is applied asa postharvest treatment and helps to reduce diseases of grapes and sweet cherries (Romanazzi et al., 2007; Hernandez-Munoz, 2008; Dang et al., 2010; Chailoo et al., 2011). Research of Romanazzi et al. (2002) has shown that chitosan can replace fungicides to combat postharvest damage of grapes.

Taking into account a widespread use of chitosan for storing fruits, we set the goal to study its influence on storage duration and quality of sour cherries fruits.

\section{MATERIALS AND METHODS}

\subsection{Preharvest and postharvest treatments}

Sour cherry variety Shpanka, collected in 2016 at the stage of eating ripeness, was used for storage. Four trees were selected randomly according to the following variants: control (without treatment), treatment with chitosan solution in concentrations $0.5 \%$ and $1.0 \%$. On the day before harvesting, the fruits were sprayed with $0.5 \%$ or $1 \%$ chitosan solution with a mechanical mist sprayer $\left(7.51\right.$ tree $\left.^{-1}\right)$ and dried naturally. Fruits were loaded in box №5 with a capacity of $5 \mathrm{~kg}$ and kept at a the temperature of $5{ }^{\circ} \mathrm{C} \pm 0.5$ and relative humidity not lower than $95 \pm 1 \%$.

One week before harvesting 100 fruits from each tree (or variants) were selected for further analytical determinations: mass loss, sugar content decrease reduction, total acidity, ascorbic acid and respiration rate. Analytical determinations were made in recentlyharvested fruits (day 0 ) and in fruits that were stored for 7,15 , and 21 days at $5{ }^{\circ} \mathrm{C}+1$ day at $20^{\circ} \mathrm{C}$ by using one lot for each variant and treatment selected randomly from the storage room. Experiment was repeated three times and then the mean values of all results were calculated.

\subsection{Analytical methods}

After storing the commercial quality of products was determined. To determine commercial quality, the sour cherry fruits of the first commercial quality were selected after storage. By their appearance they were typical in form and color for the pomological variety. Fruits were homogeneous in degree of maturity, not overripe and no smaller than $16 \mathrm{~mm}$ in size. The number of fruits without a peduncle and with healed damages was not higher than $4 \%$. The fruits were of the same size, color and shape without damages (average diameter is about $15.51 \pm 0.05 \mathrm{~mm}$ ).

\subsection{Fruit mass loss}

At the end of storage, natural mass loss was measured by weighting. Mass loss was calculated as the difference of two weightings before and after storage expressed as a percentage. The criteria for the end of storage was the mass loss no more than $6 \%$.

\subsection{Determining respiration rate}

Sour cherry samples weighing $200 \mathrm{~g}$ were put into exicator for 2 hours, meanwhile generated $\mathrm{CO}_{2}$ reacted with $20 \mathrm{ml} 0.4 \mathrm{M} \mathrm{NaOH}$. The respiration rate was determined by titration with $0.2 \mathrm{M}$ oxalic acid and expressed as milliliter $\mathrm{CO}_{2} \mathrm{~kg}^{-1}$ (fresh mass) per hour. Three repetitions were carried out for each sample.

The ferricyanide method was used for sugar content analysis (Naichenko, 2001). The content of titrated acids was determined by titration with a solution of 0.1 $\mathrm{M} \mathrm{NaOH}$. Ascorbic acid content was determined using the modified method of Tillmans. The solution was titrated with 2.6-dichloroindophenol under acid conditions (Naichenko, 2001).

\subsection{Statistical analysis}

The data were statistically processed using a single and two factors analysis of variance (ANOVA) at significance level $\mathrm{P}<0.05$ on the $\mathrm{PC}$ program Statistica (Mamchich, 2006). Variances were the time of storage and type of treatment. 


\section{RESULTS AND DISCUSSION}

Results (Table 1) have shown that storage duration of sour cherries in the control variant was 15 days, in the experimental variants was 21 days, which is 1.4 times longer.

Table 1: The output of standard products from sour cherry fruits

\begin{tabular}{lccc}
\hline Variant & $\begin{array}{c}\text { Shelf life } \\
(\text { days })\end{array}$ & $\begin{array}{c}\text { Mass loss } \\
(\%)\end{array}$ & The standard number of products $(\%)$ \\
\hline Control & 15 & $5.7 \pm 1.6$ & $79.6 \pm 2.3$ \\
$0.5 \%$ chitosan & 21 & $5.2 \pm 1.5$ & $81.6 \pm 3.1$ \\
$1 \%$ chitosan & 21 & $4.6 \pm 1.3$ & $0.6 \pm 2.2$ \\
LSD $_{05}$ & & 0.8 & 0.6 \\
\hline
\end{tabular}

An important indicator of preservation is natural mass loss. The experimental results show that for sour cherries in the control variant, the average mass loss was $5.7 \%$. The mass loss of treated fruits were $5.2 \%$ and $4.6 \%(0.5 \%$ and $1 \%$ solution of chitosan $)$, which is $8.8 \%$ and $19 \%$ less than control.

An important indicator of fruit quality after storage is marketability evaluation, which determines the competitiveness of products in the market. According to the research results, output of marketable products after 15 days of storage in the control was $79.6 \%$. Whereas for fruits treated with chitosan solution, storage duration was longer by 6 days and made up 21 days. The output of standard products in the fruits treated with $0.5 \%$ chitosan solution was higher by $2 \%$ and treated with $1 \%$ solution of chitosan - by $5.9 \%$ and accounted for $85.5 \%$. Results are consistent with the results of El Ghaouth (1991) and Romanazzi et al. (2003).

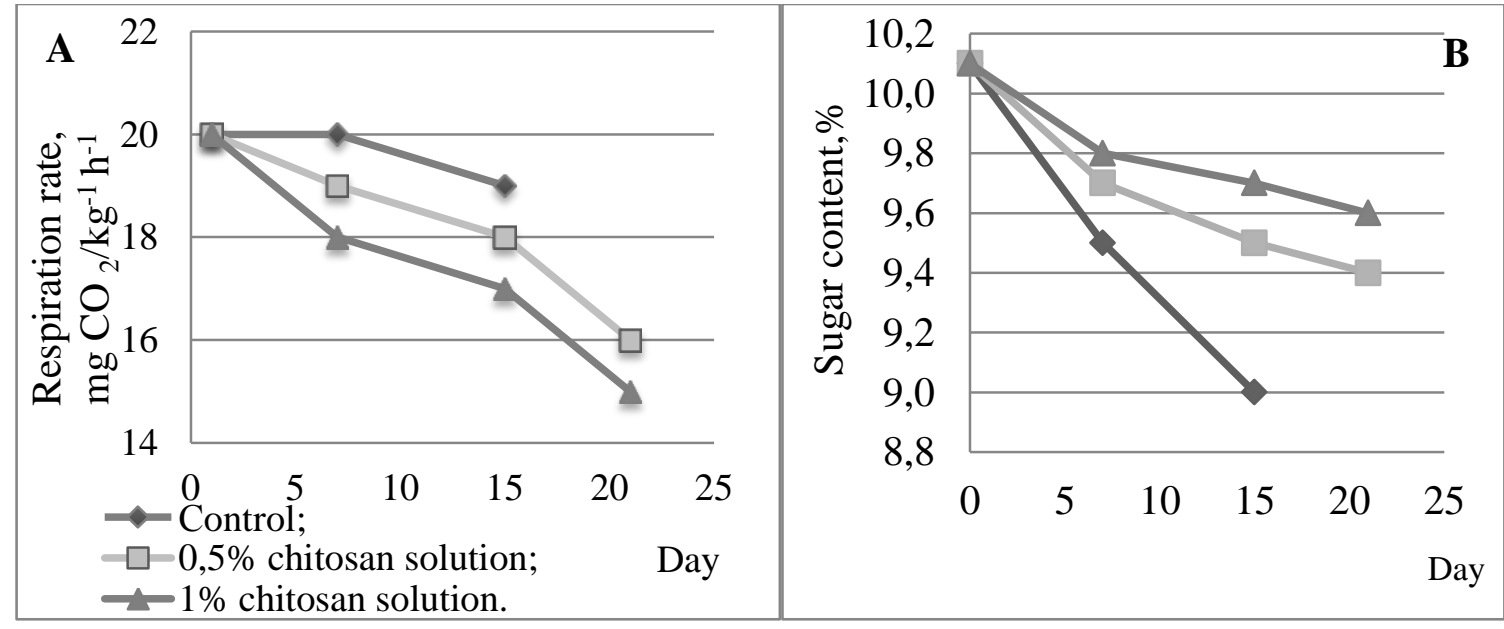

Figure 1: Changes in respiration rate $(A)\left(\mathrm{LSD}_{05}=1.2\right)$ and total sugar content $(\mathrm{B})\left(\mathrm{LSD}_{05}=0.2\right)$ in sour cherries treated with chitosan solution during storage

Chitosan treatment changed the respiration rate of sour cherry (Figure 1). In particular, from the 1 st to the 7 th day of storage, it remained similar in all variants. On the 7 th, 15th and 21 st day of storage the respiration rate of chitosan treated fruitwas by $1-3 \mathrm{mg} \mathrm{CO} / \mathrm{kg}^{-1} \mathrm{~h}^{-1}$ lower. The obtained results are consistent with the data of
Petriccione et al. (2015) and Romanazzi et al. (2013). It could be explained by the fact that the chitosan coating forms a semipermeable film on the surface of fruits and vegetables, slowing respiration rate, reducing weight loss, improving quality and prolonging storage. 
One of the main substrates of respiration of fruits are sugars and acids. Figure $1 \mathrm{~B}$ shows the change in the total content of sugars during the storage. The content of total sugar in sour cherry fruit treated with 1 or $0.5 \%$ chitosan solutions decreased throughout the storage period by $5 \%$. Content of sugar depended on treatment. It remained the highest in fruit treated with $1 \%$ chitosan solution and made up $9.6 \%$, which is $6.7 \%$ higher than control.

Figure 2A shows the change in the acid content of the fruits during storage. After 15 days of storage there was a threefold decrease in the content of titrated acids in the fruits of the control variant. Acid loss in sour cherry fruit treated with $0.5 \%$ solution of chitosan is lower by $44 \%$, and lower by $33 \%$ in fruits treated with $1 \%$ solution of chitosan.

During storage, the content of ascorbic acid also significantly decreased (Figure 2B). The content of ascorbic acid decreased throughout the storage period by 1.7 times. In addition, the content of ascorbic acid in fruits, treated with $0.5 \%$ and $1 \%$ chitosan solution decreased by $27 \%$ and $18 \%$. Our results are in agreement with previous studies (Dang et al., 2010; Kerch, et al., 2011 and Petriccione et al., 2015).
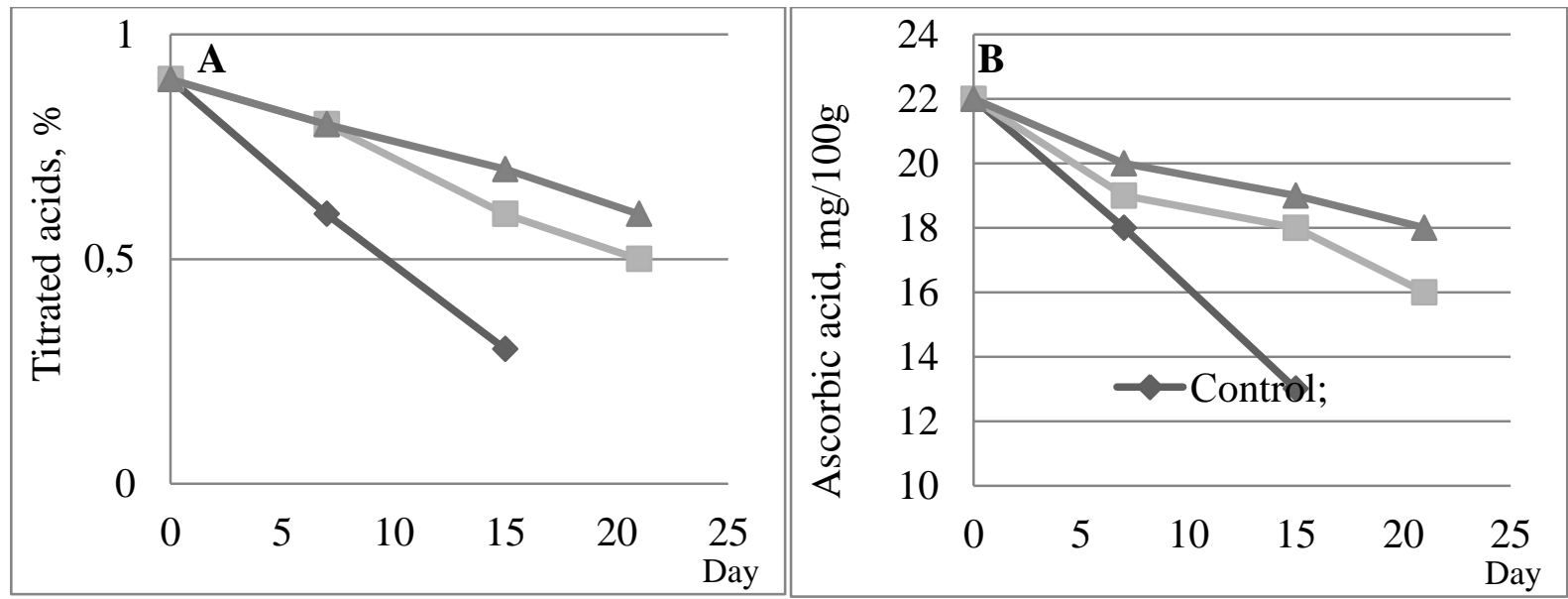

Figure 2: : Influence of chitosan solution on the content of titrated acids $(A)\left(\mathrm{LSD}_{05}=0.2\right)$ and ascorbic acid $(\mathrm{B})$ $\left(\mathrm{LSD}_{05}=1.5\right)$ in sour cherries during storage

\section{CONCLUSIONS}

It has been established that postharvest treatment of sour cherries with $1 \%$ solution of chitosan has a positive influence and improves the commercial quality of fruits. After 21 days of storage of sour cherry fruits the mass loss made up $4.6 \%$ with $85.5 \%$ output of marketable products. The obtained results are consistent with physiological and chemical changes in the fruits during storage. The respiration rate of the fruits decreased, the loss of sugars does not exceed $6.7 \%$, acids $-33 \%$, and ascorbic acid $-18 \%$.

\section{REFERENCES}

Ahmed, M.J., Singh, Z., Khan, A.S. (2009). Postharvest Aloe vera gel-coating modulates fruit ripening and quality of 'Arctic Snow' nectarine kept in ambient and cold storage. International Journal of Food Science \& Technology, 44, 1024-1033. doi:10.1111/j.1365-2621.2008.01873.x

Chailoo, M.J., Asghari, M.R. (2011). Hot water and chitosan treatment for the control of postharvest decay in sweet cherry (Prunus avium L.) cv.
Napoleon (Napolyon). Journal of Stored Products and Postharvest Research, 2(7), 135-138.

Chernozubenko, N.K. (1993). Determination of suitability of new varieties of black currants and cherries for storage and processing. Thesis. Kyiv.

Dang, Q.F., Yan, J.Q., Li, Y., Cheng, X.J., Liu, C.S., Chen, X.G. (2010). Chitosan acetate as an active coating material and its effects on the storing of Prunus avium L. Journal of Food Science, 75(2), 125-131. doi:10.1111/j.1750-3841.2009.01483.x 
El Ghaouth, A., Arul, J., Wilson, C., Benhamouc, N. (1997). Biochemical and cytochemical aspects of the interactions of chitosan and Botrytis cinerea in bell pepper fruit. Postharvest Biology and Technology, 12(2), 183-194. doi:10.1016/S09255214(97)00056-2

El Ghaouth, A., Arul, J., Ponnamapalam, R., Boulet, M. (1991). Chitosan coating effect on storability and quality of fresh strawberries. Journal of food science, 56(6), 1618-1620. doi:10.1111/j.13652621.1991.tb08655.x

Genskowsky, E., Puente, L.A., Perez-Alvarez, J.A., Fernandez-Lopez, J., Munoz, L.A., Viuda-Martos, M. (2015). Assessment of antibacterial and antioxidant properties of chitosan edible films incorporated with maqui berry (Aristotelia chilensis). Food Science and Technology, 64, 1057-1062.

Hernandez-Munoz, P., Almenar, E., Del Valle, V., Velez, D., Gavara, R. (2008). Effect of chitosan coating combined with postharvest calcium treatment on strawberry (Fragaria ananassa) quality during refrigerated storage. Food Chemistry, 110, 428-435. doi:10.1016/j.foodchem.2008.02.020

Kerch, G., Sabovics, M., Kruma, Z., Kampuse, S., Straumite, E. (2011). Effect of chitosan and chitooligosaccharide on vitamin $\mathrm{C}$ and polyphenols contents in cherries and strawberries during refrigerated storage. European Food Research and Technology, 233(2), 351-358. doi:10.1007/s00217011-1525-6

Mamchich, T.I., Olenko, A.Ya., Osipchuk, M.M., Shportyuk, V.G. (2006). Statistical analysis of data with the STATISTICA package. Drohobych.

Naichenko, V.M. (2001). Practicum on technology of storage and processing of fruits and vegetables. Kyiv.

Paronian, V.H., Kureghian, T.P., Komarov, N.V. (2003). Progressive ways of processing fruits and vegetables before storing. Storage and processing of agricultural raw materials, 7, 23-24.

Petriccione, M., De Sanctis, F., Pasquariello, M.S., Mastrobuoni, F., Rega, P., Scortichini, M.,Mencarelli, F. (2015). The effect of chitosan coating on the quality and nutraceutical traits of sweet cherry during postharvest life. Food and Bioprocess Technology, 8(2), 394-408. doi:10.1007/s11947-014-1411-X
Romanazzi, G. (2010). Chitosan treatment for the control of postharvest decay of table grapes, strawberries and sweet cherries. Fresh Produce, 4, 111-115.

Romanazzi, G., Feliziani, E., Santini, M., Landi, L. (2013). Effectiveness of postharvest treatment with chitosan and other resistance inducers in the control of storage decay of strawberry. Postharvest Biology and Technology, 75, 24-27. doi:10.1016/j.postharvbio.2012.07.007

Romanazzi, G., Feliziani, E., Baños, S.B., Sivakumar, D. (2017). Shelf life extension of fresh fruit and vegetables by chitosan treatment. Critical Reviews in Food Science and Nutrition, 57, 579-601. doi:10.1080/10408398.2014.900474

Romanazzi, G., Karabulut, O.A., Smilanick, J.L. (2007). Combination of chitosan and ethanol to control postharvest gray mold of table grapes. Postharvest Biology and Technology, 45(1), 134-140. doi:10.1016/j.postharvbio.2007.01.004

Romanazzi, G., Nigro, F., Ippolito, A., Venere, D. DI, Salerno, M. (2002). Effects of pre- and postharvest chitosan treatments to control storage grey mold of table grapes. Journal of Food Science, 67(5), 18621867. doi:10.1111/j.1365-2621.2002.tb08737.x

Romanazzi, G., Gabler, F.M., Smilanick, J.L. (2006). Preharvest chitosan and postharvest UV irradiation treatments suppress gray mold of table grapes. The American Phytopathological Society, 90(4), 445450. doi:10.1094/PD-90-0445

Romanazzi, G., Nigro, F., Ippolito, A. (2003). Short hypobaric treatments potentiate the effect of chitosan in reducing storage decay of sweet cherries. Postharvest Biology and Technology, 29, 73-80. doi:10.1016/S0925-5214(02)00239-9

Romanazzi, G., Feliziani, E., Bautista Banos, S., Sivakumar, D. (2015). Shelf life extension of fresh fruit and vegetables by chitosan treatment. Critical Reviews in Food Science and Nutrition, 57, 579601. doi:10.1080/10408398.2014.900474

Wu, B.H., Quilot, B., Genard, M., Karvella, J., Li, S.H. (2005). Changes in sugar and organic acid concentrations during fruit maturation in peaches $P$. davidiana and hybrids as analyzed by principal component analysis. Scientia Horticulturae, 103, 429-439. doi:10.1016/j.scienta.2004.08.003

Yen, M.T., Yang, J.H., Mau, J.L. (2008). Antioxidant properties of chitosan from crab shells. Carbohydrate Polymers, 74, 840-844. doi:10.1016/j.carbpol.2008.05.003 